\title{
CAPACITY BUILDING NEEDS OF SMALL AND MEDIUM CONTRACTING ENTERPRISES IN KLANG VALLEY MALAYSIA
}

\author{
Wah-Peng Lee ${ }^{1}$, Tien-Choon Toh ${ }^{1 *}$, Yoke-Lian Lew 1 , Sin-Huai Khor ${ }^{1}$, Kai-Chen Goh², Hun-Chuen Gui³, Nadzirah Zainordin ${ }^{4}$, Chia- \\ Kuang Lee ${ }^{5}$ \\ ${ }^{1}$ Lee Kong Chian Faculty of Engineering and Science, Universiti Tunku Abdul Rahman, Kajang, Malaysia \\ 2 Faculty of Technology Management and Business, Universiti Tun Hussein Onn Malaysia, Batu Pahat, Malaysia \\ ${ }^{3}$ Faculty of Built Environment, Universiti Malaysia Sarawak, Kota Samarahan, Malaysia \\ ${ }^{4}$ Faculty of Engineering, Built Environment and Information Technology, SEGi University, Petaling Jaya, Malaysia \\ ${ }^{5}$ Faculty of Industrial Management, Universiti Malaysia Pahang, Kuantan, Malaysia
}

ABSTRACT - This study investigated the issues constraining the growth of small and mediumscale contracting firms, which can, in turn, reflect the small and medium-scale contractors' needs that are corresponding to the needs or supports required by small and medium-scale contractors. The purpose of this study is to help SMCEs realise their own needs and also to assist government and policy makers to discover the approaches that should be executed and allocate scarce resources to the critical parts through needs identification and appraisal. A closed-ended questionnaire survey was deployed and the responses collected only reflecting the construction players that are currently working in CIDB registered Grade 1 to Grade 6 contracting enterprises in the Klang Valley area. Through factor analysis, five critical needs have been identified. They are technical and technological needs, job accessibility needs, favourable fiscal and monetary policy needs, business development needs and anti-corruption needs. Besides, this study revealed that the success of SMCEs can be perceived in the aspects of their business growth, profit growth and employment growth. Research studies on this topic are limited in the Malaysian construction industry. Therefore, this study provides guidances and references for SMCEs and policy makers concerning the capacity building needs and how their successes can be achieved, so that SMCEs can be assisted in a way that is truly able to build their capabilities in today's construction sector in Malaysia.

\author{
ARTICLE HISTORY \\ Received: 4-3-2020 \\ Accepted: $12-5-2020$ \\ KEYWORDS \\ Capacity building needs; \\ Small and medium \\ contracting enterprises; \\ Klang Valley Malaysia
}

\section{INTRODUCTION}

Construction industry does not operate solely, yet it is a sophisticated cluster that involving various sectors such as financing, stock and machinery supply, contractors, consultants and others. This sector able to contribute to the economic development of every county. It provides more job opportunities especially to those unskilled workers, encourages the enhancement of technology transfer and boosts more businesses that immediately enhance standard of living of people (Windapo and Cattell, 2013). Capable small and medium-sized contracting firms (SMCEs) are crucial to the development of nation as they generate more total output of the nation by decreasing unemployment rate and encouraging more entrepreneurs to start up more businesses in the nation which can subsequently improve the country's performance (Sitharam and Hoque, 2016). This view is supported by Razak, Abdullah and Ersoy (2018) who mention that Malaysia truly looking into the development of business that is small and medium in size since small and medium-sized enterprises (SMEs) as part of the economic is an important sector that not only can improve the growth of Gross Domestic Profit (GDP) and stimulate economic to another higher level, it is also treated as a ground where businessman can build up their aptitude and potential to expand their business.

SMCEs in Malaysia play vital role in the development of country triggered the reason why government care about their development. However, they are more vulnerable to both external and internal environment and consequently cause them encounter higher risks compared to other sectors (Jaafar and Abdul-Aziz, 2005; Razak, Abdullah and Ersoy, 2018). Even though the firms are in the same construction industry, the needs for different sizes of companies to enhance their capabilities are different, and when compared to the large companies are also different. Thus, this study is to fill the research gap to investigate the capacity building needs to provide the support that truly demanded by SMCEs in the Malaysian construction industry. Since there is limited research pertaining to capacity building needs of small and medium-scale construction firms especially contracting firms in Malaysia, so this research is conducted to offer guidances and references for those SMCEs and also for government to understand and support SMCEs in a way that is truly able to build their competences in the current environment setting. 


\section{LITERATURE REVIEW}

\subsection{Small and Medium Sized Contracting Enterprises (SMCEs) in Malaysia}

Numerous studies pertaining the research on SMEs in non-construction sector have attempted to define SMEs based on the sales turnover and the number of full time employees in the company. However, Siong (2000) cited in Jaafar and Abdul-Aziz (2005) points out that majority of the Malaysia contracting firms are on project basis. The main contract are mostly diversified and subcontracted out to other contractors. Thus, it is makes sense to argue that contracting firms unlikely need large amount of full time employees and asset that equivalent to their project portion. This view is supported by Kamal and Flanagan (2012) who define SMCEs in his research according to the definition recognized by CIDB as well.

Table 1: Classification of contracting firms based on the criteria provided by CIDB (Kamal and Flanagan, 2012)

\begin{tabular}{cccc}
\hline CIDB Registration Grade & $\begin{array}{c}\text { Tendering Capacity } \\
\text { (RM) }\end{array}$ & $\begin{array}{c}\text { Financial Capacity } \\
(\mathbf{R M})\end{array}$ & Size of Contractor \\
\hline G1 & Not exceeding 200,000 & 5,000 & Small \\
G2 & Not exceeding 500,000 & 25,000 & Small \\
G3 & Not exceeding 1 million & 50,000 & Small \\
G4 & Not exceeding 3 million & 150,000 & Medium \\
G5 & Not exceeding 5 million & 250,000 & Medium \\
G6 & Not exceeding 10 million & 500,000 & Medium \\
G7 & No limit & 750,000 & Large \\
\hline
\end{tabular}

In this research, the definition of SMCEs is based to the classification of contractor's registered grade with CIDB whereby G1 to G6 contractors are categorized as SMCEs. Contractor is classified in term of their tender limit and minimum paid up or accumulated capital. The categorization of contractors based on CIDB registered grade is adopted from the research of Kamal and Flanagan (2012). Small contractors from G1 to G3 must at least have minimum RM 5,000 paid up capital to be able to tender for projects below RM 1 million. G4 to G6 contracting firms are categorized as medium-scale contractors and need to have financial capacity of at least more than RM 150,000 to RM 500,000. They can bid for projects of not more than RM 10 million in value. G7 are large-scale contractors who must have minimum RM 750,000 paid up capital and can bid for projects regardless of its value.

\section{Concept of Capacity Building Needs}

Asante, Kissi and Badu (2018) draw out the attention that previous research of Committee of Donor Agencies for Small Enterprise Development (1997) has defined "SMEs needs" as particular obstacles encountered to achieve firm's sustainability. The team drawn out the argument of "SME needs" is reflected as "challenges, problems, constraints or barriers" and all these terms as implicit support for SMEs in order to facilitate them in removing barriers. Sobeck and Agius (2007) state that even though capacity building is not approach or policy, but it still gives rise countless and immeasurable definitions where in his research highlights that Elliott (2003) defines capacity building as having sufficient capital to attain desired results while Freeman and Roming (2005) describe "capacity is a resource-based perspective and focuses on the inputs and outputs of an organisation".

While a variety of definitions of the terms "capacity building needs" have been suggested, this paper uses the definition suggested by Asante, Kissi and Badu (2018) who studied the topic of capacity building needs in a substitute way by examining and exploring the "challenges, problems, constraints or barriers to the growth" of SMEs. The study concentrates on issues constraining the growth of small and medium-scale contracting firms, which can, in turn, derived to small and medium-scale contractors' needs which is corresponding to the need or support required by small and medium-scale contractors.

\section{Capacity Building Needs of SMCEs in Klang Valley Malaysia}

Capability of an organisation can be influenced by the aspects inside the company such as fund and aspects outside the company such as their capacity to stand out among their competitors. Funding management is the most significant aspect in company management (Eniola and Entebang, 2015). As claimed by Jaafar and Abdul-Aziz (2005), the two most vital survival practice is to be skillful in finance as well as accounting because imprecision and incapability in management commonly lead to failure of young firms. Besides cash flow management, SMCEs have to properly manage their time to achieve timely completion on construction activities and projects. Followed by their capability to acquire and retain needed competence staff and professional. Frost (2003) points out corporate manager or owner have to stress on the importance to take care of their managerial staff and sustain a lean group of core staff as Lansley et al. (1979) found that effective human resource management should be emphasising on employees' welfare, morale and job satisfaction. Other management skills include quality of their work on site which is one of the most essential parameters in term of their project performance. Other skills contain monitoring and ensuring healthy and safety environmental as well as manage their subcontractors. The financial constraint that hinders small contracting firms from constructing their firm's capacity is worsened by the inadequacies in the construction sector whereby project owner tend to delay contractor's payment which is not an uncommon issue in the industry. Consequently, contractors suffer from the late 
payments from the project owners would end up they become the one who default and most serious implication is that the company will goes into liquidation. Most of the contracting firm's reputation is ruined as their trustworthy with bank is affected in such condition (Eyiah, 2001; Thwala and Mvubu, 2009).

Besides, conflict of public interest which is commonly discovered in mega projects. Contracts are being awarded to those who have relations with public servants or local politician through corruption. Consequently, potential bidders lose the opportunity even though they offered the best value of tender to government. Also, some government staff perceived that large companies have greater ability to provide benefits compared to SMCEs and this mindset eventually affect the outcome of tendering in public procurement (Akenroye and Aju, 2013). In addition, they still constrained by the difficulty in accessing to financial resources for some reasons such as being told that they are unqualified, lack of track records or lengthy processing time. They do not have adequate collateral demanded by bank in order to get funds (Razak, Abdullah and Ersoy, 2018). Due to inadequate collateral, they have no choice but to depend on paying unaffordable interest and high financial risk management fees if they still intend to get loan from bank. The project they won subsequently becomes pointless as it turns out no gain (Thwala and Mvubu, 2009). If transparency in procurement procedure is enhanced, the less likelihoods of misuse and mishandling of the procurement process to occur (Hui et al., 2011). An example has been given by Akenroye and Aju (2013) pertaining the practice of lack of transparency in his research is that when government do not stated the proposed contract sum of the open tender project while advertising. It might result in misconception of small and medium-sized contractors assuming that the contract opportunities published are suitable for large contracting firms only. Most importantly, tender evaluation standards and its weightings were not commonly made known. Such pattern of publishing need to be revised in order to minimize possibility of disqualified contractors to be able to participate in public procurement through grey area that may affect the advantages of non-large-scale contractors. As shown in World Bank study, the problems of bribery is seemed as a barrier to the development of small firms compared to huge corporations because paying bribes is a burden for SMEs to run their business with limited resources (Daniel and Alina, 2012).

Role of local, regional and federal government in introducing several programmes and policies is important to directly and indirectly support SMCEs from aspects of funding, training, counselling and supervising. These policies should be initiated by various government departments and institutions as well as private sector. Some research found that most of the small and medium-scale contractors has not been fully exploiting the benefits and assistance as much as they should receive from available platforms. This condition happens as a result of deficiencies in communication flow and their accessibility (Nhlumayo, 2017). Improvement of staff as well as top management's skills is dominant to company performance in knowledge-based economies. SMCEs less likely have the capability to offer training due to their financial constraints (OECD, 2002). Widerstedt and Mansson (2014) point out the measure to apply for state assist to pay for business counselling. Considerable performance enhancement of firms in the construction sector is relied upon price steadiness in building material costs. Inflation increases in the price of site materials resulting in low cost overall performance of building projects, create uncertainty into contract pricing and bidding, possibly influence efficiency of contractors' future cash flow particularly as performing projects that take long duration, and hence could cause project failure due to not sufficiently mark up to captivate price escalation, contributing contracting firms or construction industry unable to stand strong (Windapo and Cattell, 2013). One of the key aspects related to the issue of monetary support is high interest rates that are connected with the provision of loans by financial institutions. The principal myth is that high interest rates on loans are the key feature off-putting the establishment of young SMEs and development of established SMEs. Consequently, SMCEs unable to invest more in new plant and equipment, affecting in SMEs ability to recruit more employers (Sawaya and Bhero, 2017).

Continuous flow of work has been a challenge to construction SMCEs as they are small and their job as contractor are project-basis. They would not be able to know when the time of next project is available for them (Kamal and Flanagan, 2012). Information failure is one of the common failures happened in public procurement system. It means one of the party in economic transaction owns greater source of information comparing to the other party (EBRD, 2017). Fundamentally, they would not be able to directly win the contract that is large in amount, however they can obtain works through subcontracting from the large-scale contractors who won big contracts (Abbott, Blackburn and Curran, 1996). The project owner no longer constantly adopt the lowest tender guideline when awarding a contract as the lowest price may deliver the lower quality performance in most contracts. Hence, client gives extra consideration to the tenderer who have past working experience and has built the good working relationship with him. Apart from that, contractors had been forced to re-adjust their companies' strategies by diversifying into different construction-related jobs in order to gain sufficient turnover. Different construction-related corporations and services such as property development, property maintenance, mechanical and electrical works, road and infrastructure works, fabrication and supply of workplace and home furniture, as supplier of construction materials such as sand and aggregates, and pharmaceutical works (Nhlumayo, 2017). Emerging contractor lack of knowledge regarding government project contracting procedure. Small firms have less human capital, money and time to comprehend the excessive bureaucracy in the tendering process that only applied in the public procurement system (EBRD, 2017). Akenroye and Aju (2013) also point out that with regards to the complex tendering procedure, the duration for small contractors to prepare tender is too short for them. Traditionally, it is the professional bodies that plan and offer their member's education and training. However, this contributes to the fragmentation of the different construction professions with the related fixed structure of staff development. This drive the variety of professionals that involve in a construction project team and other industry stakeholders perceived that it possibly much wiser and practical to create nationwide organized and integrated training programme for professionals, concentrating on a cohesive approach to mutual difficulties and values in construction sector (Asmy and Mohammed, 
2013). Kamal and Flanagan (2012) emphasize that SMCEs can't afford to provide the capital to utilize in the development of technology which need to incur the costs for knowledge and expertise. Adoption of upgraded technology is therefore as the bedrock of forming a more competent industry, involving the efforts of both large-scale construction firms and small and medium-sized contractors (Kamal and Flanagan, 2012). According to Thwala and Mvubu (2009), lack of financial capacity resulting in SMCEs inability to meet the tender bond and performance bond requirement both prior to awarding contracts and during the contract period has disqualified them from securing contracts. Taxes raise the production price of goods and services which would ultimately cause additional charges to the final products and services to final consumers. With numerous and high taxes, the prices become escalating. As a result, firm's profit is lessened.

\section{Perceived Success of SMCEs}

Success is the outcome of a well-coordinated of resources and capabilities in the corporations to stimulate the growth of firms (Machado, 2016). This research conceptualizes the success of SMCEs referring to the research of Arthur-Aidoo, Aigbavboa and Thwala (2016) who define the success of construction SMCEs by utilizing the particulars of company's growth indicators. SMCEs' success is defined in terms of number of projects engaged in the firm, the profit generated by the firm and the number of workforces. Volume of company sales is reflected as the typical attribute of growth measure. In the context of construction field, it is referring to the number of projects engaged in the firm which can also be described in the term as business growth. Al-Matari, Al-Swidi, Fadzil (2014) claim that the business's performance can be observed from the financial statement reported by the firm. These three aspects like profitability, growth and market value are the features that counterpart to each other. Market value indicates the price in the market or the financial asset such as company shares should raise value in the marketplace. It is named as profit growth in this research. Besides, Brüderl and Preisendörfer (2000) cited in Tajnikar, Ponikvar and Bonča (2016) state that "a company is viewed as fast growing when it doubles its employment and creates at least five additional jobs within five years". This statement is supported by Almus (2002) cited in Tajnikar, Ponikvar and Bonča (2016) who adopts the identical definition. It is termed as employment growth in this research.

\section{METHODOLOGY}

\section{Survey as the Research Method}

Nineteen variables are derived from literature review and is used to develop a structured questionnaire. The aim of distributing questionnaire to SMCEs is to determine the perceptions of small (G1 to G3) and medium-sized (G4 to G6) contracting enterprises towards the significance level of the capacity building needs and perceived success. They are required to evaluate and rank the significant level of each variable using scale ranging from 1 to 5 where $1=$ strongly disagree, 2 = disagree, 3 = neutral, 4 = agree, 5 = strongly agree.

\section{Sampling and Sample Size}

Sample size of this research is determined whereby the targeted respondents are only limited to the construction players that working with CIDB registered G1 to G6 contracting enterprises located within Klang Valley area. A total sample size of 145 was considered for the study which included $29 \%$ of the respondents are from small-sized contracting enterprises while the remaining $71 \%$ of the respondents are from medium sized contractor firms. Respondents from managerial level or top management were a total of 40 respondents are Managing Director, Director, Senior Manager, Manager and Assistant Manager. Other respondents are holding the position as executive, quantity surveyor, engineer and supervisor. Majority of the category of work that the respondents' company normally involved in for building work is at $61.4 \%$. The contractor firm of respondents that involving in non-building work including civil engineering, mechanical and engineering (M\&E) and facility management are lesser which is at $38.6 \%$. In the aspect of years of experience of respondents, the amount are almost equally disseminated where as much as $53.1 \%$ respondents have working experience that less than 5 years while $46.9 \%$ respondents have been working in the industry for 5 years and above.

\section{FINDINGS AND DISCUSSION}

Data collected is analyzed by using SPSS. This research applied mean ranking to rank each variable by using their mean computed. Each variable is ranked according to perception of respondents on the significant level of the variable. The greater the mean value, the more significant the variable is. For the variable that have similar mean value, the variable with lower standard deviation is considered more important. The top five most significant capacity building needs of SMCEs are identified among the needs. There are (1) developing professional skills; (2) facilitating technological upgrading; (3) reducing high taxes; (4) developing managerial skills; (5) facilitating accessibility to plant. 
Table 2: Ranks of SMCEs needs

\begin{tabular}{llccc}
\hline & \multicolumn{1}{c}{ SMCEs Needs } & \multicolumn{3}{c}{ Overall (N=145) } \\
\cline { 3 - 5 } Ref & & Mean & SD & Rank \\
\hline N01 & Developing managerial skills & 4.15 & 0.758 & 4 \\
N02 & Promoting prompt payment system & 4.06 & 0.734 & 9 \\
N03 & Discouraging political interference in awarding contract & 4.01 & 0.754 & 11 \\
N04 & Reviewing collateral requirements & 3.97 & 0.772 & 15 \\
N05 & Enhancing transparency in public procurement & 4.08 & 0.731 & 8 \\
N06 & Curbing demand of bribe & 4.10 & 0.779 & 7 \\
N07 & Strengthening SME development policies & 3.90 & 0.743 & 17 \\
N08 & Providing business counselling & 3.92 & 0.859 & 16 \\
N09 & Controlling inflation & 4.01 & 0.726 & 10 \\
N10 & Controlling high interest rate & 3.99 & 0.795 & 14 \\
N11 & Providing work opportunities & 4.13 & 0.748 & 6 \\
N12 & Reserving portion of government contracts & 4.01 & 0.804 & 12 \\
N13 & Providing marketing skills & 4.01 & 0.829 & 13 \\
N14 & Simplifying procurement processes & 3.68 & 1.040 & 19 \\
N15 & Developing professional skills & 4.37 & 0.633 & 1 \\
N16 & Facilitating accessibility to plant & 4.14 & 0.754 & 5 \\
N17 & Facilitating technological upgrading & 4.24 & 0.700 & 2 \\
N18 & Relaxing bond requirement & 3.80 & 0.787 & 18 \\
N19 & Reducing high taxes & 4.16 & 0.723 & 3 \\
\hline
\end{tabular}

Table 3: Ranks of perceived success

\begin{tabular}{clcccc}
\hline & \multirow{2}{*}{ Ref } & & \multicolumn{3}{c}{ Overall $(\mathbf{N}=145)$} \\
\cline { 3 - 5 } PS01 & Business growth & Mean & SD & Rank \\
\hline PS02 & Profit growth & 4.28 & 0.629 & 1 \\
PS03 & Employment growth & 4.10 & 0.680 & 2 \\
\hline
\end{tabular}

Factor analysis (FA) is utilized to categorize the variables into different groups. It is very useful for detecting sets of correlated factors and consequently is idyllic for decreasing an enormous number of variables into a more simple and understandable arrangement (Asante, Kissi and Badu, 2018). According to Pallant (2011), assessment on the suitability of data must be conducted prior to factor analysis. Bartlett's test of sphericity must demonstrate a value below 0.05 and Kaiser-Meyer-Olkin (KMO) must show a value of at least 0.6 and above, in order to generate a good factor analysis. The factor is then extracted, rotated and interpreted. Through careful examination of the components, five components had been successfully identified and there are as follows:

(1) Factor 1: Technical and technological needs

(2) Factor 2: Job accessibility needs

(3) Factor 3: Favourable fiscal and monetary policy needs

(4) Factor 4: Business development needs

(5) Factor 5: Anti-corruption needs

\section{Factor 1: Technical and technological needs}

The first factor consists of variables including facilitating technological upgrading (0.854), facilitating accessibility to plant (0.777) and developing professional skills (0.727). It accounts for the total variance of 36.942\%. This factor is termed as technical and technological needs as the variables are considered have interrelationship with each other. Obsolete technology is the hindrance towards the growth and sustainability of SMCEs. Despite the fact that adopting enhance technology able to improve the efficiency as well as the quality of works, they have limited resources to invest in such technology innovation compared to affordable labour cost. The funds incurred not only on the plant and machinery itself, but also acquire the overheads for operators and training (Kamal and Flanagan, 2012).

Limited funding capital has inhibited SMCEs from assessing to the advance technology in order to achieve the revolution of company performance in term of their technical capacity (Sexton, Barrett and Aouad, 2006). Eliminating old mentality, awareness on the need to gain fresh knowledge and enhance their level of skills in technology innovation able to develop a firm's performance (Hardie and Newell, 2011). Knowledge and skills of human capital in operating the plants is an issue that must be considered prior to making the move towards technology enhancement towards the firm. SMCEs must have the ability to engage the expertise to the firms as well as take the matter pertaining their employee's absorptive capacity into consideration (Bushe, 2019). This concern regarding the firm's administrative abilities is crucial as it able to stimulate SMCEs growth in remarkably fast paced (Sexton, Barrett and Aouad, 2006). Well-trained and 
capable professional staff no matter recruit externally or train internally for their profession improvement creates values to construction SMEs (Asmy and Mohammed, 2013). Razak, Abdullah and Ersoy (2018) describe that right people must be allocated in the right position where their expertise can be fully exploit. Hence, SMCEs need to attract and retain skillful and competent workforce in their firm in order to build the firm's capacity to survive in this competitive environment (Carroll et al., 1999).

Table 4: Rotated component matrix for SMCEs needs

\begin{tabular}{|c|c|c|c|c|c|c|}
\hline \multirow[b]{2}{*}{ Ref } & \multirow{2}{*}{ Description } & \multicolumn{5}{|c|}{ Factor } \\
\hline & & 1 & 2 & 3 & 4 & 5 \\
\hline N17 & Facilitating technological upgrading & 0.854 & & & & \\
\hline N16 & Facilitating accessibility to plant & 0.777 & & & & \\
\hline N15 & Developing professional skills & 0.727 & & & & \\
\hline N12 & Reserving portion of government contracts & & 0.784 & & & \\
\hline N11 & Providing work opportunities & & 0.649 & & & \\
\hline N18 & Relaxing bond requirement & & 0.624 & & & \\
\hline N07 & Strengthening SME development policies & & 0.442 & & & \\
\hline N04 & Reviewing collateral requirements & & 0.441 & & & \\
\hline N05 & Enhancing transparency in public procurement & & 0.410 & & & \\
\hline N19 & Reducing high taxes & & & 0.831 & & \\
\hline N10 & Controlling high interest rate & & & 0.622 & & \\
\hline N14 & Simplifying procurement processes & & & 0.615 & & \\
\hline N09 & Controlling inflation & & & 0.615 & & \\
\hline N08 & Providing business counselling & & & & 0.877 & \\
\hline N13 & Providing marketing skills & & & & 0.725 & \\
\hline N01 & Developing managerial skills & & & & 0.481 & \\
\hline N03 & $\begin{array}{l}\text { Discouraging political interference in awarding } \\
\text { contract }\end{array}$ & & & & & 0.702 \\
\hline N06 & Curbing demand of bribe & & & & & 0.683 \\
\hline N02 & Promoting prompt payment system & & & & & 0.456 \\
\hline
\end{tabular}

\section{Factor 2: Job accessibility needs}

The second factor explains the intercorrelated variables of reserving portion of government contracts $(0.784)$, providing work opportunities (0.649), relaxing bond requirement (0.624), strengthening SME development policies (0.442), reviewing collateral requirements (0.441) and enhancing transparency in public procurement (0.410). It accounts for the total variance of $8.789 \%$. This factor is named as job accessibility needs as these variables have adverse influence on SMCEs in getting jobs.

Continuous flow of work has been a challenge to construction SMEs as they are restricted by their financial capacity and contractor jobs are obtained through project-basis (Kamal and Flanagan, 2012). Their tendering capacity is based on their firm's size which is categorised in term of their financial capacity. They are restricted from tendering for the projects that are large in value unless they subcontract the job from the large-scale contractors who won big contracts in order to ensure their continuity of jobs and stimulate their turnover (Abbott, Blackburn and Curran, 1996). Also, accessibility of information influences SMCEs towards realise the business-related chances and getting involved in the market (EBRD, 2017). According to Thwala and Mvubu (2009), SMCEs are normally have limited capital and thus inability to meet the tender bond and performance bond requirement before projects tendering has disqualified them from getting projects. Hence, business support and services mainly focusing on SMCEs that consists of credit guarantee scheme, the setting up of equity, and private sector funding (Nhlumayo, 2017) as well as making sure SMCEs has obtained the support that they supposed to get (Razak, Abdullah and Ersoy, 2018) is essntial. Akenroye and Aju (2013) also claim the issue regarding transparency in public procurement whereby stating the proposed contract sum of the open tender project able to avoid potential SMCEs from losing chances of getting public jobs. The consequence is that in the lack of job opportunities, most of the SMCEs would be losing of revenue and development in their reputation and credit worthiness where Razak, Abdullah and Ersoy (2018) support that SMEs often encountered the trouble in getting to funding resources due to their qualification and track records as well as unable to meet the collateral requirements set by financial institutions in order to obtain funding to run company's operation. By facilitating job accessibility and financial needs, it would ultimately develop the capacity of SMCEs.

\section{Factor 3: Favourable fiscal and monetary policy needs}

The third factor groups the variables of reducing high taxes (0.831), controlling high interest rate (0.622), simplifying procurement processes $(0.615)$ and controlling inflation (0.615). It accounts for the total variance of $6.446 \%$. This factor has been given a term as favorable fiscal and monetary policy needs as these variables are closely related to the policies imposed by government and central bank. 
Government fiscal policy in adjusting the tax rates paid by firms able to influence overall GDP of the country. Taxation paid by firms act as funding sources for government expenditure and contribute to economic growth. However, it has drawbacks towards the growth and sustainability of SMEs. High taxes lead to higher goods and services prices such as construction materials, and it would definitely diminishes the firm's earnings (Mungaya, Mbwambo and Tripathi, 2012). On the other hand, one of monetary policy instruments is the rate of interest which is controlled by central bank, Bank Negara Malaysia (BNM). Fisher (1930) cited in Akalpler and Duhok (2018) claims that the connection between revenue and funds is the interest rate. The higher the interest rate, the higher the cost of borrowing. It subsequently discourages borrowers from getting loans. As a result, SMCEs do not have the additional capital to expand their businesses (Sawaya and Bhero, 2017). Inflation must be controlled by government as price stability have direct impact not only towards the rates of building materials but also escalates the project contract sums. Contractor firms may encounter profit erosion in the cases that the projects they engaged in are in firm price basis whereby they have to solely bear for the implication of rising material costs as a result of inflationary (Oghenekevwe, Olusola and Chukwudi, 2014). Besides, excessive red-tape in the tendering process that is found in the public procurement system is a hindrance towards the development of SMCEs as public project requires a number of knowledge, workforces, money and time to comprehend it. Potential SMCEs may be discouraged in tender for public projects due to their limited absorptive capacity on the highly legalized process, terms and conditions and overregulated processes (EBRD, 2017). Hence, government has the obligation to take SMCEs into their consideration while reviewing and executing policies in order to make cost of borrowing affordable as well as manage the economy sensibly to minimize the escalation of goods and services rates in an economy.

\section{Factor 4: Business development needs}

Moreover, the fourth factor is called as business development needs which comprises of providing business counselling (0.877), providing marketing skills (0.725) and developing managerial skills (0.481). It accounts for the total variance of $5.708 \%$.

Competencies and capabilities of top management and executives is the key to a firm's performance in this knowledgebased economies. OECD (2002) states that official organization counselling able to reduce the chances of business closedown resulting from incapability in management. Due to the limited capital of SMCEs to pay for formal training, Widerstedt and Mansson (2014) claim that state-assist business counselling is therefore crucial to offer competitive advantages to SMCEs for ensuring them able to survive and compete with larger firms in this competitive market. Small firms can joint venture or form affiliation with firms that have greater capability to create stronger capacity to firm. Contracts awarded by client no longer viewed lowest bid as their first choice, they also consider the previous performances and experiences of the firms. Hence, company employees must be able to perform and maintain good working relationship with client as they represent their company. Firm's decision makers also play vital roles in diversifying their firm into other construction-related jobs to enhance firm's margin (Nhlumayo, 2017). In term of administration, financial management is the most momentous part within company management as incapability in managing company cash flow has been discovered as one of the main reasons of company goes for liquidation by CCH Research (2013) in Bushe (2019). A company must have practiced proper documentation keeping, time management, quality management and health and safety environmental management. The most important resources in a company is its human resources. A firm must have the capability to attract and retain good employee inside their firm as their performance can directly influence the firm's performance (Frost, 2003). Therefore, these variables are clumped into one group asthese aspects are closely related to the competence and capability of a firm's human capital and is able to be controlled within the firm itself, and hence it is named as business development needs.

\section{Factor 5: Anti-corruption needs}

The fifth factor is termed as anti-corruption needs. Variables such as discouraging political interference in awarding contract (0.702), curbing demand of bribe (0.683) and promoting prompt payment system (0.456) are assembled under this factor. It accounts for the total variance of $5.313 \%$. This factor is categorised as anti-corruption needs.

The misuse of political power to interrupt the decision making in planning, organizing, staffing, directing, coordinating, addressing, and budgeting, distributing and utilizing of public funds (Mfuru, Sarwatt and Kanire, 2018) potentially contributes to the failure of SMCEs. Contracts are awarded to those private firms that have political affiliations with performed public servants instead of based on the tenderer's performance (Khan et al., 2019). This point of view is supported by Ateljevic and Budak (2010) who state that one of the challenges towards the growth of SMCEs is when more and more contracts cannot be secured by SMCEs as they do not have political influence in government contracting bidding process. The illegal connection between performing public servants and private organization are formed by paying bribes and other benefits. SMCEs have less power to reject such corruption and it eventually caused additional burden to them. This kind of unlawful action has a tendency to influence the capacity of SMCEs to compete for projects on an impartial basis. Thus, it must be handled as a matter of economic developmental concern.

\section{CONCLUSION}

Capable small and medium-sized contracting firms (SMCEs) are vital to the economic performance of the country as they create numerous job opportunities and contribute to the GDP of the nation (Sitharam and Hoque, 2016). This study helps to ascertain the approaches that should be implemented and aids to prioritise resources allocation to the critical aspects through needs identification and evaluation. The outcomes able to help SMCEs to realise their needs. This 
research ensures that what has been provided to SMCEs is truly what is needed by them through fulfilling the gap in between. This study has discovered and appraised the capacity building needs of SMCEs in Klang Valley Malaysia. The study discovered five critical needs through the use of factor analysis. These five critical needs ascertained include technical and technology support, offering job opportunities and financial aid, execution of favourable fiscal and monetary policy, provision of business growth services and inhibit corruption. The outcomes and discussion of the findings strengthen the long-held awareness that different barriers encountered by SMCEs can be overcome if only they are supported. This study also demonstrates that all the factors explored are perceived to have a significant effect on their growth. From a strategy side, the findings deliver clues on what the invention of any future capacity intervention should focus. The findings also determine that the perceived success of SMCEs can be measured in term of their business growth, profit growth and employment growth.

Provided the significant role of SMCEs play in the nation whereby this industry is a complex cluster that gathered other field of the economic, this research suggests the provision of technical and technological upgrading to SMCEs which has been discovered as the most concerned need by construction players from the research outcome. Business associations should be encouraged to foster technology transfer and generate job prospects in the construction field to enhance the track records and credit worthiness of SMCEs. For long term, the policy makers should create a conducive business environment for SMCEs through the formulation of fiscal and monetary policy. The significant of management capacities within the firm itself should be realized by stakeholders of company for gaining competitive advantages that make them stand out against other firms. Lastly, this research bring out the standing of government to aware the loopholes for corrupt practices that SMCEs should be protected from, and shall restrict this issue through strict enforcement of the law.

\section{REFERENCES}

Abbott, B., Blackburn, R. A. \& Curran, J. (1996). Local Authority Privatisation and Markets for Small Businesses. Local Government Studies, 23(3), 72-89.

Akalpler, E. \& Duhok, D. (2018). Does Monetary Policy Affect Economic Growth: Evidence from Malaysia, Journal of Economic and Administrative Sciences, 34(1), 2-20.

Akenroye, T. O. \& Aju, O. (2013). A Taxanomy of Approaches for Promoting SMEs Access to Public Procurement Market. Journal of Enterprising Culture, 21(03), 335-357.

Al-Matari, E. M., Al-Swidi A. K. \& Fadzil, F. H. (2014). The Measurements of Firm Performance's Dimensions. Asian Journal of Finance \& Accounting, 6(1), 24-49.

Almus, M. (2002). What Characterizes a Fast-Growing Firm? Applied Economics, 34(12), 1497-1508. DOI: $10.1080 / 00036840110105010$

Arthur-Aidoo, M. B., Aigbavboa, C. O. \& Thwala W. D. (2016). Conceptualising Growth of Small and Medium-Sized Construction Firms in Ghana. Proceedings of 4th International Conference Socio-economic Researchers, 172-180.

Asante, J., Kissi, E. \& Badu, E. (2018). Factorial Analysis of Capacity-Building Needs of Small- and Medium-Scale Building Contractors in Developing Countries: Ghana As A Case Study, Benchmarking, 25(1), 357-372.

Asmy, M. \& Mohammed, M. O. (2013). The Challenges of Micro Enterprises in Malaysia and the Prospect for Integrated Cash Waqf Microenterprise Investment (ICWME-I) Model, IIUM Repository, 1-18.

Ateljevic, J. \& Budak, J. (2010). Corruption and Public Procurement: Example from Croatia, Journal of Balkan and Near Eastern Studies, 12(4), 375-397.

Brüderl, J. \& Preisendörfer, P. (2000). Fast-Growing Businesses: Empirical Evidence from a German Study, International Journal of Sociology, 30(3), 45-70.

Bushe, B. (2019). The Causes and Impact of Business Failure Among Small to Micro and Medium Enterprises in South Africa, Africa's Public Service Delivery and Performance Review, 7(1), 1-26.

Carroll, M., Earnshaw, J., Marchington, M. \& Taylor, S. (1999). Recruitment in Small Firms: Processes, Methods and Problems, Employee Relations, 21(3), 236-250.

CIDB. (2018). Construction Industry Review \& Prospect 2018/2019. Retrieved July 11, 2019, from http://www.cidb.gov.my/images/content/pdf/bisnes/prospect20182019/CIDB---Construction-Industries-Review-2018-2019min-1.pdf.

Daniel, B. \& Alina, B. (2012). Corruption As Constraint in SMEs Financial Management (I - Concept and Economic Impact), Journal of Electrical and Electronics Engineering, 5(1), 7-12.

EBRD (2017). Is Open Competition Good for Small and Medium-Sized Enterprises? Retrieved July 14, 2019, from http://www.ebrd.com/documents/ogc/public-procurement-is-open-competition-good-for-smes.pdf.

Elliott, G. L. (2003). Measuring capacity and capacity building in nonprofit organizations: A large sample study of Americorps VISTA. Paper presented at 32nd Annual Conference of the Association for Research on Nonprofit Organizations and Voluntary Action. Denver, CO.

Eniola, A. A. \& Entebang, H. (2015). SME Firm Performance-Financial Innovation and Challenges, Procedia - Social and Behavioral Sciences. 195, 334-342.

Eyiah, A. K. (2001). An Integrated Approach to Financing Small Contractors in Developing Countries: A Conceptual Model, Construction Management and Economics, 19(5), 511-518.

Fisher, I. (1930). The Theory of Interest, The Online Library of Liberty, Liberty Fund Inc., 2005, Macmillan Company, available at: http://oll.libertyfund.org/Home3/index.php

Freeman, D. E. \& Roming, L. (2005). The Unity Foundation's C.Q.: Capacity benchmarking and capacity building. In L. Bartczak, (Ed.), A funder's guide to organizational assessment (pp. 97-111). St. Paul, MN: Fieldstone Alliance.

Frost, F. A. (2003). The Use of Strategic Tools by Small and Medium-Sized Enterprises: An Australasian Study, Strategic Change, $12(1), 49-62$. 
Hardie, M. \& Newell, G. (2011). Factors Influencing Technical Innovation in Construction SMEs: An Australian perspective, Engineering, Construction and Architectural Management, 18(6), 618-636.

Hui, W. S., Othman, R., Omar, N. H., Rahman, R. A. \& Haron, N. H. (2011). Procurement Issues in Malaysia, International Journal of Public Sector Management, 24(6), 567-593.

Jaafar, M. \& Abdul-Aziz, A.-R. (2005). Resource-Based View and Critical Success Factors: A Study on Small and Medium Sized Contracting Enterprises (SMCEs) in Malaysia, International Journal of Construction Management, 5(2), 61-77.

Kamal, E. M. \& Flanagan, R. (2012). Understanding Absorptive Capacity in Malaysian Small and Medium Sized (SME) Construction Companies, Journal of Engineering, Design and Technology, 10(2), 180-198.

Khan, A., Waris, M. Ismail, I., Sajid, M. R., Ullah, M. \& Usman, F. (2019). Deficiencies in Project Governance: An Analysis of Infrastructure Development Program, Administrative Sciences, 9(9), 1-15.

Lansley, P., Quince, T. \& Lea, E. (1979). Flexibility and Efficiency in Construction Management, Final Report on a Research Project with Financial Support of the DoE (Unpublished), Building Industry Group, Ashridge Management Research Unit, Berkhamsted.

Machado, H. P. V. (2016). Growth of Small Businesses: A Literature Review and Perspectives of Studies. Journals of Entrepreneurship and Small Business Management, 23(2), 419-432.

Mfuru, A. W. E., Sarwatt, A. C. \& Kanire, G. (2018). The Impact of Political Interference in Public Administration in Kibaha Town. Global Journal of Political Science and Administration. 6(4), 21-31.

Mungaya, M., Mbwambo, A. H. \& Tripathi, S. K. (2012). Study of Tax System Impact on the Growth of Small and Medium Enterprises (SMEs): With reference to Shinyanga Municipality, Tanzania. IJMBS, 2(3), 99-105.

Nhlumayo, S. P. (2017). The Impact of Government-Driven Initiatives for the Success of Small Medium Enterprises (SMEs) in KwaZulu-Natal, South Africa. Retrieved July 28, 2019 from https://www.semanticsscholar.org/paper/The-impact-ofgovernment-driven-initiatives-for-the-Nhlumayo/2316c2bd1a8ddfa9fb6eb54bcae10449ff74025f.

Oghenekevwe, O., Olusola, O. \& Chukwudi, U. S. (2014). An Assessment of the Impact of Inflation on Construction Material Prices in Nigeria. PM World Journal. 3(4), 1-22.

Pallant, J. (2005). SPSS survival manual: A step by step guide to data analysis using SPSS. 6th ed. Berkshire: Open University Press.

Razak, D. A., Abdullah, M. A. \& Ersoy, A. (2018). Small Medium Enterprises (SMES) in Turkey and Malaysia a Comparative Discussion on Issues and Challenges, International Journal of Business Economics and Law, 15(3), 1-10.

Sawaya, A. \& Bhero, S. (2017). Are Interest Rates A Deterrent to SMEs Growth in Mozambique?, European Journal of Business and Management, 9(29), 33-41.

Sexton, M., Barrett, P. \& Aouad, G. (2006). Motivating Small Construction Companies to Adopt New Technology, Building Research and Information, 34(1), 11-22.

Siong, W. S. (2000). Menangani Masalah Ekonomi: Satu Kajian ke atas Firma-Firma Kontraktor (trans: Overcoming Economic Problems: A Case Study on Construction Firms), Unpublished MSc Thesis, Universiti Sains Malaysia, Penang, Malaysia.

Sitharam, S., \& Hoque, M. (2016). Factors Affecting the Performance of Small and Medium Enterprises in KwaZulu-Natal, South Africa. Problems and Perspectives in Management, 14(2), 277-288.

Sobeck, J. \& Agius, E. (2007). Organizational Capacity Building: Addressing A Research and Practice Gap, Evaluation and Program Planning, 30(3), 237-246.

Tajnikar, M., Ponikvar, N. \& Bonča, P. D. (2016). Characteristics of Firms with Different Types of Growth: The Case of Slovenia. Economic Annals, 61(208), 27-47.

Thwala, W. D. and Mvubu, M. (2009). Problems Facing Small and Medium Size Contractors in Swaziland, Journal of Service Science and Management, 02(04), 353-361.

Widerstedt, B. \& Mansson, B. W. J. (2015). Can Business Counselling Help SMEs Grow? Evidence from the Swedish Business Development Grant Programme, Journal of Small Business and Enterprise Development, 22(4), 652-665.

Windapo, A. O. \& Cattell, K. (2013). The South African Construction Industry: Perceptions of Key Challenges Facing Its Performance, Development and Growth, Journal of Construction in Developing Countries, 18(2), 65-79.

\section{ACKNOWLEDGEMENT}

This research was supported by Universiti Tunku Abdul Rahman, Sungai Long Campus, Malaysia. The authors would like to thank Assistant Professor Dr Felicia Yong Yan Yan for her suggestions on preparing the manuscript.

\section{DECLARATION OF CONFLICT OF INTEREST}

The authors declare that there is no conflict of interest regarding the publication of this paper.

\section{AUTHORS' BIOGRAPHY}

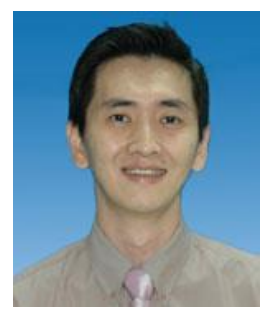

Wah-Peng Lee is an Assistant Professor in Lee Kong Chian Faculty of Engineering and Science at Universiti Tunku Abdul Rahman, Sungai Long Campus, Malaysia. He received his PhD (Project Management) and MBA (Finance) from Universiti Putra Malaysia, and BEng (Hons) (Civil and Structural Engineering) from Universiti Kebangsaan Malaysia. 


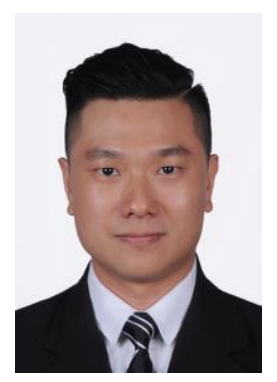

Tien-Choon Toh is an Assistant Professor in Lee Kong Chian Faculty of Engineering and Science at Universiti Tunku Abdul Rahman, Sungai Long Campus, Malaysia. He received his PhD (Quantity Surveying), MSc (Construction Management), BSc (Hons) (Construction), and Dip in Quantity Surveying from Universiti Teknologi Malaysia.

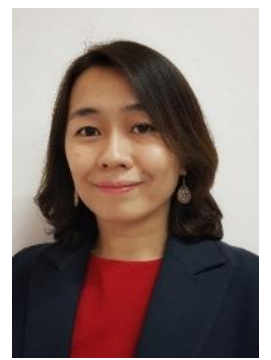

Yoke-Lian Lew is an Assistant Professor in Lee Kong Chian Faculty of Engineering and Science at Universiti Tunku Abdul Rahman, Sungai Long Campus, Malaysia. She received her PhD (Project Management), MSc (Project Management) and BEng (Hons) (Civil) from Universiti Putra Malaysia, and Dip in Civil Engineering from Politeknik Ungku Omar.

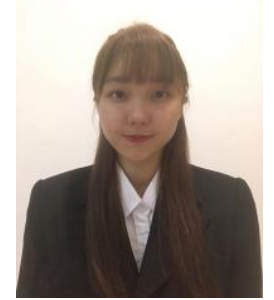

Sin-Huai Khor is a Former Undergraduate Student in Lee Kong Chian Faculty of Engineering and Science at Universiti Tunku Abdul Rahman, Sungai Long Campus, Malaysia. She received her BSc (Hons) (Quantity Surveying) from Universiti Tunku Abdul Rahman.

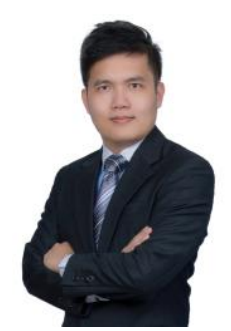

Kai-Chen Goh is an Associate Professor in Faculty of Technology Management and Business at Universiti Tun Hussein Onn Malaysia, Malaysia. He received his PhD (Built Environment and Engineering) from Queensland University of Technology, and MSc (Construction Management), BSc (Hons) (Construction) and Dip in Quantity Surveying from Universiti Teknologi Malaysia.

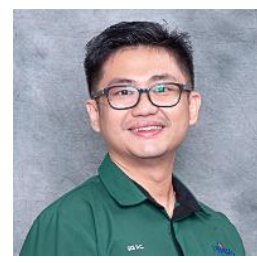

Hun-Chuen Gui is a Senior Lecturer in Faculty of Built Environment at Universiti Malaysia Sarawak, Malaysia. He received his MSc (Construction Management) and Bachelor of Quantity Surveying (Hons) from Universiti Teknologi Malaysia. 
Nadzirah Zainordin is a Senior Lecturer in Faculty of Engineering, Built Environment and Information Technology at SEGi University, Malaysia. She received her MSc (Quantity Surveying) from Heriot-Watt University and BSc (Hons) (Quantity Surveying) from Twintech International University College of Technology.

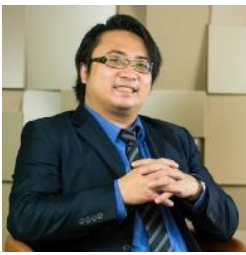

Chia-Kuang Lee is a Senior Lecturer in Faculty of Industrial Management at Universiti Malaysia Pahang, Malaysia. He received his PhD (Civil Engineering) from The University of Auckland, and MSc (Construction Contract Management) and Bachelor of Quantity Surveying (Hons) from Universiti Teknologi Malaysia. 